\title{
Increased Frequency of the S-allele of the L-myc Oncogene in Breast Cancer
}

\author{
Turgay İsbir, ${ }^{1}$ İlhan Yaylim,, ${ }^{1}$ Soykan Arîkan, ${ }^{2}$ Seden Küçücük, ${ }^{3}$ and Hakan Çamlíca ${ }^{4}$ \\ ${ }^{1}$ Institute of Experimental Medical Research, Department of Molecular Medicine, University of Istanbul, \\ Turkey \\ ${ }^{2}$ Haseki Research and Educational Hospital, Surgery Clinic, Istanbul, Turkey \\ ${ }^{3}$ University of Istanbul, Institute of Oncology, Istanbul, Turkey \\ ${ }^{4}$ University of Istanbul, Institute of Oncology, Division of Cancer Epidemiology and Bioistatistics, Istanbul, \\ Turkey
}

Accepted July 12, 2002

\begin{abstract}
Background: Association between restriction fragment length polymorphisms (RFLP) of known oncogenes and a predisposition to develop cancer have been postulated. The L-myc gene is a potential molecular marker associated with cancer susceptibility as well as metastasis, prognosis, and adverse survival. Our aim was to test the hypothesis that there was an association between $\mathrm{L}$-myc $\mathrm{S}$ allele in breast cancer and a predisposition to the disease.

Materials and Methods: The distribution of L-myc polymorphism in 56 patients with breast cancer was determined by polymerase chain reaction-based restriction fragment length polymorphism and compared with that of 51 healthy control subjects.
\end{abstract}

Results: The allele frequencies of $\mathrm{L}$ and $\mathrm{S}$ in breast cancer patients were 0.70 and 0.30 , respectively and those in normal individuals were 0.54 and 0.46 , respectively. This difference was primarily the result of a high frequency of the $S$ allele among breast cancer patients compared to controls. The frequency of S allele was significantly higher in breast cancer patients than in normal individuals $(p<0.01)$. No correlation was observed between the presence of L-myc $S$ allele and several parameters of each patient's history or characteristics of tumor.

Conclusion: Our results suggested that L-myc polymorphism may be significant in an individual's susceptibility to breast cancer in Turkey and may be useful for identifying patients at high risk of developing breast cancer.

\section{Introduction}

Breast cancer is a genetic disease, with most breast cancer cases resulting from a dysregulation of genetically determined cellular pathways. The occurance of cytogenetic abnormalities affecting chromosome 1 in a number of breast tumors led us to examine, at the molecular level, loci located on chromosome 1 in primary breast tumor DNAs (1). Association between restriction fragment length polymorphism (RFLPs) of known oncogenes and a predisposition to develop cancer have been reported by a number of authors $(2,3)$. Since the cloning of L-myc gene in 1985, an enormous amount of research has been conducted to help elucidate the importance of this gene in human malignancy. Eco RI restricted human DNAs show fragment length polymorphism of L-myc (chromosome lp 32) defined by 2 alleles: $10.0 \mathrm{~kb}(\mathrm{~L})$ and $6.6 \mathrm{~kb}(\mathrm{~S})$ fragments (4). Previous studies have reported that patients showing either the homozygous S-band (S-S) or the heterozygous S and L-band (L-S) suffered a much higher incidence of metastasis and

Address correspondence and reprint requests to: T. Isbir, İstanbul Üniversitesi, DETAE 34390, P.O. Box 7, Çapa/

İstanbul TURKEY. Phone/fax: +9021263519 59,

e-mail: tisbir@superonline.com.tr a poor prognosis for several cancers (5-8). Other investigators, however, failed to find such an association in lung cancers (9-12), colorectal cancers (13), non-Hodgkin's lymphomas (14), and acute lymphocytic leukemias (15).

In the present study PCR-RFLP method was used to analyze the distribution of L-myc polymorphism both in patients with breast cancer and healthy Turkish females in an attempt to resolve the debate as to whether any relationship exists between polymorphism and the risk of developing breast cancer.

\section{Materials and Methods Subjects}

L-myc gene polymorphism has been studied among 56 breast cancer patients (mean age 56,9 $\pm 10,73$; age range 32-74 years) and 51 age-matched female non-malignant healthy subjects. Healthy persons without any malignancy were selected for the control group (mean age; $54.3 \pm 12.01$; age range $32-74$ years). Subjects were selected from two education hospitals in Istanbul between 2000-2001. Diagnosis of breast cancer done by surgical clinics relied upon mammography, ultrasonography, and finally pathological examination. Controls were selected from 


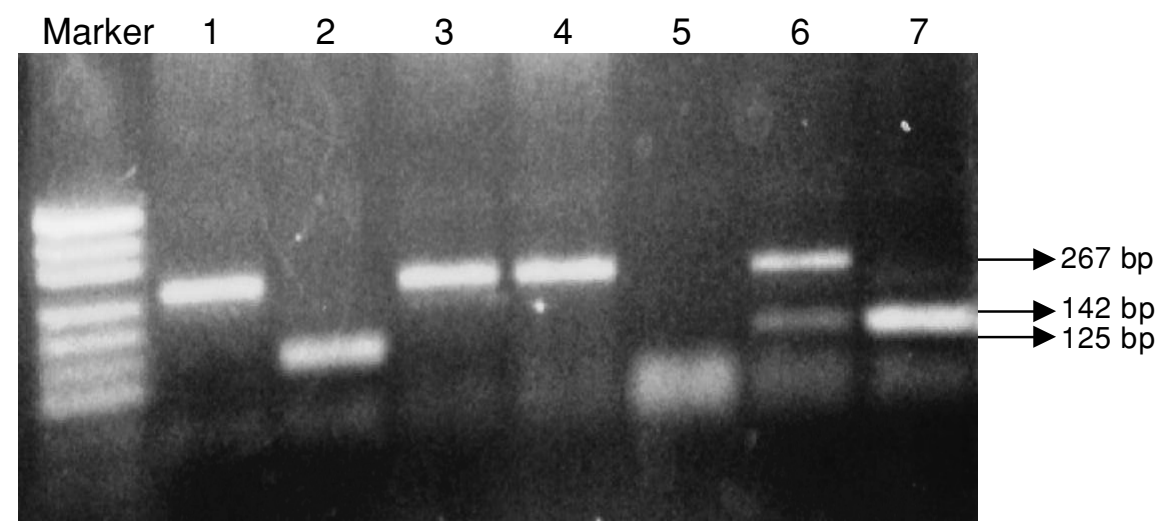

Fig. 1. Direct visualization of PCR products by ethidium bromide staining. A 267-base pair L-myc fragment was amplified, cleaved with Eco RI, and electrophoresed on a $2 \%$ agarose gel. Results from seven representative breast cancer patients are shown. Lanel: LL homozygote; lane 2: SS homozygote; lane 3-4: LL homozygote; lane 5: no PCR product; lane 6: LS heterozygote; lane 7: SS homozygote. The marker band uses (bp) are from top to bottom: 501, 404, 331, 242, 190, 147, 111, and 67.

surgery policlinics and clinics among the people who had no proven malignant disease or disease history and were in the same age group with the breast cancer patients. All the breast cancer patients and controls were citizens of the Turkish republic; no minority people were included in this study. Detailed medical history, physical examination, and pathological diagnosis were performed for all patients in the study. The samples were collected before any chemotherapeutic or radiation therapy treatment had been started. A standardized questionnaire was administrated to collect data concerning age, sex, family history of breast cancer, and family history of any kind of cancer for only 56 breast patients from whom we obtained blood samples.

\section{Isolation of DNA}

Blood specimens from all subjects were collected into tubes containing EDTA. DNA was isolated from the blood leukocytes in $10 \mathrm{ml}$ EDTA by the method of Miller et al. based on sodium dodecyl sulphate lysis, ammonium acetate extraction, and ethanol precipitation (16).

\section{Polymerase Chain Reaction (PCR) for L-myc Oncogene}

Template DNA (0.5-1.0 ug) was used in a PCR under sterile conditions. $100 \mathrm{ng}$ of primer was used for the reaction. The forward primer was 5'-AGT TCA CTC ACA GGC CAC AT-3' and the reverse primer was $5^{\prime}$ TGC ATA TCA GGA AGC TTG AG-3' in a volume of $50 \mu \mathrm{l}$ containing $3 \mathrm{mM} \mathrm{MgCl} 2,50 \mathrm{mM}$ $\mathrm{KCl}, 10 \mathrm{mM}$ Tris-HCl (pH:8.4), $0.5 \mathrm{mM}$ of each dNTP (MBI Fermentas), and l unit of Taq polymerase (MBI Fermentas). Amplification was carried out in a DNA thermal Cycler (MJ Research Techne) for 30 cycles with denaturation steps at $94^{\circ} \mathrm{C}$ for 30 seconds, annealing at $50^{\circ} \mathrm{C}$ for $1 \mathrm{~min}$, and extension at $74^{\circ} \mathrm{C}$ for $1 \mathrm{~min}$. The PCR product exhibited a 267 base pair fragment. The amplified DNAs were all digested with 5 units Eco RI (MBI Fermentas) at $37^{\circ} \mathrm{C}$ for $1 \mathrm{~h}$. The digested DNA fragments were separated by gel electrophoresis on $2 \%$ agarose gel in lxTris borate EDTA buffer and DNA visualized by ethidium bromide staining. Oncogene polymorphism was typed by visualization under ultraviolet light and was photographed with a Polaroid camera. The responsible L-myc RFLP alleles were identified in each sample (9). The three genotypes were the L-L homozygote appearing as 267-base pair (bp) fragment, the L-S heterozygote with 267,142 , and 125 -bp fragments, and the S-S homozygote with 142 and 125-base pair fragments (Fig. 1).

\section{Statistical Analysis}

Statistical analyses were performed using the SPSS version 7.5 including the Chi Square $\left(\chi^{2}\right)$ test and allele frequencies composition. L-myc allele frequencies were estimated by gene counting methods. Odds ratios (ODs) and $95 \%$ confidence intervals $(95 \% \mathrm{CI})$ were calculated.

\section{Results}

The polymorphic L-myc gene locus was analysed by PCR-RFLP for 56 breast cancer patients and 51 healthy individuals. The L-myc oncogene genotypes and allele frequencies for breast cancer and control subjects are shown in Table 1.

Table 1. Distribution of L-myc restriction fragment length polymorphism genotypes in patients with breast cancer and control subjects

Control Subjects

Breast Cancer $(n=51)$ Patients $(\mathrm{n}=56)$

\begin{tabular}{lll}
\hline L-myc genotype & & \\
L-L & $0.45(23)$ & $0.20(11)$ \\
L-S & $0.51(26)$ & $0.69(39)$ \\
S-S & $0.04(2)$ & $0.11(6)$ \\
LL & $0.45(23)$ & $0.20(11)$ \\
LS + SS & $0.55(28)$ & $0.80(45)$ \\
& $\chi^{2}=7.98 ;$ & \\
df $=1$ & \\
& $p=0.005$ & \\
&
\end{tabular}

* The number of individuals is shown in parenthesis. 
Frequencies of L-L, L-S, and S-S genotypes among the patients with breast cancer were $0.20(\mathrm{n}=11)$, $0.69(n=39)$, and $0.11(n=6)$; among the control subjects, there were $0.45(n=23), 0.51(n=26), 0.04$ $(n=2)$, respectively. There was a significant increase in the frequency of genotypes containing the $S$ allele in the breast cancer population compared with the frequency in the normal population $\left(\chi^{2}=7.98\right.$; $\mathrm{p}=0.005$ ) (Table 1.). The relative risk (Odds ratio) of breast cancer for those with the LS plus SS genotypes compared with the LL genotype was 1.91 (95\% CI $=1.134-3.200)$.

The family histories of cancer were analysed in 24 of the patients. Breast cancer patients whose first, second, or third degree relatives have any kind of history of cancer and who have $S$ allele have almost a 1.05 times higher predisposition to breast cancer than those with LL genotype (95\% CI $=1.053-7.453)$.

\section{Discussion}

The L-myc gene was initially identified by Nau et al. (4) as a gene with structural similarity to c-myc and $\mathrm{N}$-myc from a human small cell lung cancer cell line and was further characterized and sequenced by Kaye et al. (17). An Eco RI restriction fragment length polymorphism in the L-myc gene can be used to distinguish alleles (4). Many reports have suggested that individuals bearing the "short" (S) allele either have an increased incidence of certain tumors and/or that such tumors manifest a more aggressive behaviour. The associated tumors include soft-tissue sarcomas (18), oral cancers (19), colorectal cancers (6), non-Hodgkin's lymphoma (20), and breast cancer (21).

Bieche et al. (1) found that a significantly shorter period after relapse was observed for patients with loss of heterozygosity at L-myc in primary tumor DNAs compared with patients with tumor DNAs lacking this alteration. Champeme et al. (21) reported that there was a statistical correlation between L-myc RFLP and lung metastasis in breast cancer patients who relapsed. In this study a significant difference was found in the distribution of L-myc genotypes between breast cancer patients and healthy individuals. Our results supported the hypothesis that the L-myc locus is involved in a genetic predisposition to breast cancer. In contrast to our results, Champeme et al. reported that no differences in the patterns of L-myc RFLP were found between breast cancer patients and healthy individuals (21). The results of our study supported that the L-myc gene is related to genetic susceptibility to breast cancer as Togo et al. (22) suggest. We studied women as a control group for L-myc RFLP analysis. They reported that the statistically significant effect observed in their study was due to the increased prevalance of the $S$ allele in breast cancer group and they analyzed women separately (22).

Multiple epidemiologic studies have documented that a reported history of breast cancer among relatives is a reproducible predictor of breast cancer risk (In general a "positive family history" of breast cancer confers a relative risk of 2.0 to 3.0 for breast cancer (23). The relationship between risk factors for breast cancer in women with or without a positive family history of this disease has been explored (24, 25). In our study we found that breast cancer patients whose first degree relatives have any kind of history of cancer and who have $\mathrm{S}$ allele have almost a 1.05 times higher predisposition to breast cancer than those with LL genotype. Additional work is needed to further characterize the molecular reasons for the increased risk seen in individuals with a positive family history. It would be interesting to study whether or not a specific distribution of the L-myc RFLP can also be observed in breast cancer and to test linkage in high-risk families.

There is no published evidence for the functional significance of polymorphism in second intron of L-myc oncogene. The nucleotide sequence of the $\mathrm{S}$ allele has been determined (8) and, as expected, differs by $1 \mathrm{bp}$ in the Eco R 1 site. In addition, there was a deletion of $8 \mathrm{bp}$ in intron 2 and it was suggested that these differences might influence the transcription or splicing of the S allele (20). An alternative explanation is that the L-myc gene is not involved but is in linkage disequilibrium with a gene or genes that are important in breast cancer as well as other form of cancer. Linkage disequilibrium of L-myc with another disease-related polymorphic gene(s) appears to be a plausible explantion for the effects observed by various investigators. Spinola et al. report that the nucleotide sequence of the coding and non-coding regions of the L-myc gene (approximately $6000 \mathrm{bp}$ ) were analyzed in Italian lung cancer patients. These researchers found no polymorphism in the coding regions, but confirmed the Eco R I polymorphism (position 3109 of the gene) and determined two additional single nucleotide polymorphism (SNPs) in the 3'-untranslated region (UTR), located at position 5453 and 6130 respectively. They suggested that the differences in allele frequency and linkage disequilibrium patterns in different populations may explain the contrasting results in the Asian and Caucasian population on the role of L-myc EcoR 1 polymorphism in lung tumor prognosis (26). According to Mendoza et al., if the L-myc RFLP has linkage disequilibrium with inactivation of a certain tumor supressor gene (TSG), then the $S$ allele should be correlated with allelic loss around the TSG locus and higher malign potential. But they failed to find an association between the L-myc $S$ allele and $\mathrm{LOH}$ around this locus and not support the hypothesis of inactivation of some TSG in linkage disequilibrium with L-myc RFLP (27). Although we were not able to investigate a linkage disequilibrium pattern between L-myc- Eco R 1 and its other sites, it would be valuable to find out the linkage disequilibrium patterns of the L-myc gene. 
We also suggest that L-myc RFLP analysis might therefore be an important factor predicting a higher risk for breast cancer, at least in the Turkish population. However, further studies of well characterised large patient groups of defined ethnicity are needed to ascertain the role of $S$ allele in breast cancer.

\section{Acknowledgements}

This study was supported by a grant from the University of Istanbul, Research Foundation (project 1561/16012001).

\section{References}

1. Bieche I, Champeme MH, Merlo G, et al. (1990) Loss of heterozygosity of the L-myc oncogene in human breast tumors. Hum. Genet. 85: 101-105.

2. Krontiris TG, Dimartino NA, Colb M, Parkinson DR. (1985) Unique allelic restriction fragments of the human Ha-ras locus in leukocyte and tumour DNAs of cancer patients. Nature 313: 369-373.

3. Heighway J, Thatcher N, Cerny T, Hasleton PS. (1986) Genetic predisposition to human lung cancer. Br. J. Cancer 53: 453-457.

4. Nau MM, Brooks BJ, Battey J, et al. (1985) L-myc a new mycrelated gene amplified and expressed in human cell lung cancer. Nature 318: 69-73.

5. Ishizaki K, Kato M, Ikenaga M, et al. (1990) Correlation of L-myc genotypes to metastasis of gastric cancer and breast cancer. J. Natl. Cancer. Inst. 82: 238-239.

6. Young J, Buttenshaw R, Butterworth L, et al. (1994) Association of the SS genotype of the L-myc gene and loss of 18qsequences with a worse clinical prognosis in colorectal cancers. Oncogene 9: 1053-1106.

7. Shibuta K, Inoue H, Sato K, et al. (2000) L-myc Restriction Fragment Lenth Polymorphism (RFLP) in Japanese patients with esophageal cancer. Jpn. J. Cancer Res. 91: 199-203.

8. Kawashima K, Nomura S, Hirai H, et al. (1992) Correlation of L-myc RFLP with metastasis prognosis and multiple cancer in lung-cancer patients. Int. J. Cancer. 50: 557-561.

9. Tamai S, Sugimura H, Caporaso NE, et al. (1990) Restriction fragment length polymorphism analysis of the L-myc gene locus in a case control study of lung cancer. Int. J. Cancer. 46: 411-415.

10. Tefre T, Borresen A-L, Aamdal S, Brogger A. (1990) Studies of the L-myc DNA polymorphism and relation to metastasis in Norwegian lung cancer patients. Br. J. Cancer 61: 809-812.

11. Weston A, Ling-Cawley HM, Caporaso NE, et al. (1994) Determination of the allelic frequencies of an L-myc and a p53 polymorphism in human lung cancer. Carcinogenesis 15: 583-587.
12. Yaylim İ İsbir T, Oztürk O, et al. (2002) Is there any correlation between restriction fragment length polymorphism of the L-myc gene and metastasis of human non-small cell lung cancer? Cancer Genetics and Cytogenetics 134: 118-122.

13. Ikeda I, Ishizaka Y, Ochiai M, et al. (1988) No correlation between L-myc restriction fragment length polymorphism and malignancy of human colorectal cancers. Jpn. J. Cancer. Res. 79: 674-676.

14. Fernandez T, Saranath D, Advani SH, et al. (1998) Restriction fragment length polymorphism of the L-myc oncogene in Non-Hodgkin's lymphoma patients from India. Cancer Letters 125: 165-169.

15. Chenevix-Trench G, Southall M, Kidson C. (1989) Restriction fragment length polymorphisms of L-myc and myb in human leukaemia and lymphoma in relation to age-selected controls. Br. J. Cancer 60: 872-874.

16. Miller SA, Dykes DD, Polesky HS. (1988) Simples salting out procedure for extracting DNA from human nucleated cells. Nucleic Acid Research 16: 1215-1219.

17. Kaye F, Battey J, Nau M, et al. (1988) Structure and expression of human L-myc gene reveal a complex pattern of alternative mRNA processing. Molecular and Cellular Biology 8: 186-195.

18. Kato M, Toguchida J, Honda K, et al. (1990) Elevated frequency of specific allele of the L-myc gene in male patients with bone and soft-tissue sarcomas. Int. J. Cancer 45: 47-49.

19. Saranath D, Panchal RG, Nair R, et al. (1990) Restriction fragment length polymorphism of the L-myc gene in oral cancer patients. Br. J. Cancer. 61: 530-533.

20. Crossen PE, Morrison MJ, Colls BM. (1994) Increased frequency of the $S$ allele of the L-myc oncogene in non-Hodgkin's lymphoma. Br. J. Cancer 69: 759-761.

21. Champeme MH, Bieche I, Latil A, et al. (1992) Association between restriction fragment length polymorphism of the L-myc gene and lung metastasis in human breast cancer. Int. J. Cancer 50: 6-9.

22. Togo AV, Suspitsin EN, Grigorilv MY, et al. (2000) L-myc polymorphism in cancer patients, healthy blood donors and elderly, tumor-free individuals in Russia. Int. J Cancer 85: 747-750.

23. Slattery ML, Kerber RA. (1993) A comprehensive evaluation of family history and breast cancer risk: The Utah Population Database. JAMA 270: 1563-1568.

24. Colditz GA, Rosner BA, Speizer FE. (1996) (Nurses Health Study Research Group) Risk factors for breast cancer according to family history of breast cancer. J. Natl. Cancer Inst. 88: 365-371.

25. Dunning AM, Healey CS, Pharoah PDP, et al. (1999) A systematic review of genetic polymorphism and breast cancer risk. Cancer Epidemiology, Biomarkers and Prevention 8: 843-854.

26. Spinola M, Nomoto T, Monenti G, et al. (2001) Linkage disequilibirium pattern in the L-myc gene in Italian and Japanese non-small-cell lung cancer patients. Int. J. Cancer 95: 329-331.

27. Mendoza C, Sato H, Hiyama K, et al. (2000) Allelotype and loss of heterozygosity around the L-myc gene locus in primary lung cancers. Lung Cancer 28: 117-125. 